\title{
Frailty and nutritional status in older people: the Mini Nutritional Assessment as a screening tool for the identification of frail subjects [Corrigendum]
}

Valentini A, Federici M, Cianfarani MA, Tarantino U, Bertoli A. Clin Interv Aging. 2018;13:1237-1244.

Page 1238, Patients and methods, the first two paragraphs are incorrect, the text should read as shown below.

Our data are derived from an observational study conducted at the "Tor Vergata" Polyclinic in Rome in patients aged 65 or older the main objectives of which were to evaluate the major indicators of frailty and to establish their relationship with changes in the endocrine system that occur with aging. ${ }^{35}$ Here we show the secondary analysis of the study to identify which indicators of frailty were most frequently present in a subgroup of patients with an acute stress such as hip fracture following low-energy trauma.

The study population comprised 112 elderly subjects, aged between 68 and 98 years, referred to "Tor Vergata"
Polyclinic from March 2014 to March 2015. Of these subjects, 62 subjects were enrolled as patients hospitalized in the Orthopedic Department following hip fracture, representing a population with higher frailty prevalence, and 50 subjects were enrolled as outpatients evaluated at the Department of Internal Medicine (Clinical Program on Atherosclerosis) as described in Bertoli et al. ${ }^{35}$ Patients general clinical characteristics from Table 1 in Bertoli et $\mathrm{al}^{35}$ were in part reported here in Tables 1-3 to facilitate the immediate comparison with new data and analysis.

Page 1244, References, a reference was excluded from the reference list, the missing reference is " 35 . Bertoli A, Valentini A, Cianfarani MA, Gasbarra E, Tarantino U, Federici M. Low FT3: a possible marker of frailty in the elderly. Clin Interv Aging. 2017;12:335-341."
Clinical Interventions in Aging

\section{Publish your work in this journal}

Clinical Interventions in Aging is an international, peer-reviewed journal focusing on evidence-based reports on the value or lack thereof of treatments intended to prevent or delay the onset of maladaptive correlates of aging in human beings. This journal is indexed on PubMed Central, MedLine,

\section{Dovepress}

CAS, Scopus and the Elsevier Bibliographic databases. The manuscript management system is completely online and includes a very quick and fair peer-review system, which is all easy to use. Visit http://www.dovepress. com/testimonials.php to read real quotes from published authors. 